\title{
Task 1.13 - Data Collection and Database Development for Clean Coal Technology By-Products Characteristics and Management Practices
}

\author{
Semi-Annual Report \\ July 1 - December 31, 1997 \\ By: \\ Debra F. Pflughoeft-Hassett

\section{RECRVED \\ NOV 231998 \\ OSTI}

Work Performed Under Contract No.: DE-FC21-93MC30097

For

U.S. Department of Energy

Office of Fossil Energy

Federal Energy Technology Center

P.O. Box 880

Morgantown, West Virginia 26507-0880

By

Energy \& Environmental Research Center

University of North Dakota

P. O. Box 9018

Grand Forks, North Dakota 58202-9018 


\section{Disclaimer}

This report was prepared as an account of work sponsored by an agency of the United States Government. Neither the United States Government nor any agency thereof, nor any of their employees, makes any warranty, express or implied, or assumes any legal liability or responsibility for the accuracy, completeness, or usefulness of any information, apparatus, product, or process disclosed, or represents that its use would not infringe privately owed rights. Reference herein to any specific commercial product, process, or service by trade name, trademark, manufacturer, or otherwise does not necessarily constitute or imply its endorsement, recommendation, or favoring by the United States Government or any agency thereof. The views and opinions of authors expressed herein do not necessarily state or reflect those of the United States Government or any agency thereof. 


\section{DISCLAIMER}

Portions of this document may be illegible in electronic image products. Images are produced from the best available original document. 


\section{DOE DISCLAIMER}

This report was prepared as an account of work sponsored by an agency of the United States Government. Neither the United States Government, nor any agency thereof, nor any of their employees makes any warranty, express or implied, or assumes any legal liability or responsibility for the accuracy, completeness, or usefulness of any information, apparatus, product, or process disclosed or represents that its use would not infringe privately owned rights. Reference herein to any specific commercial product, process, or service by trade name, trademark, manufacturer, or otherwise does not necessarily constitute or imply its endorsement, recommendation, or favoring by the United States Government or any agency thereof. The views and opinions of authors expressed herein do not necessarily state or reflect those of the United States Government or any agency thereof.

Available to the public from the National Technical Information Service, U.S. Department of Commerce, 5285 Port Royal Road, Springfield, VA 22161; phone orders accepted at (703) 487-4650.

\section{ACKNOWLEDGMENT}

This report was prepared with the support of the U.S. Department of Energy (DOE) Federal Energy Technology Center, Cooperative Agreement No. DE-FC21-93MC30097. However, any opinions, findings, conclusions, or recommendations expressed herein are those of the author(s) and do not necessarily reflect the views of DOE.

\section{EERC DISCLAIMER}

LEGAL NOTICE This research report was prepared by the Energy \& Environmental Research Center (EERC), an agency of the University of North Dakota, as an account of work sponsored by the U.S. Department of Energy. Because of the research nature of the work performed, neither the EERC nor any of its employees makes any warranty, express or implied, or assumes any legal liability or responsibility for the accuracy, completeness, or usefulness of any information, apparatus, product, or process disclosed or represents that its use would not infringe privately owned rights. Reference herein to any specific commercial product, process, or service by trade name, trademark, manufacturer, or otherwise does not necessarily constitute or imply its endorsement or recommendation by the EERC. 
TABLE OF CONTENTS

$1.0 \quad$ INTRODUCTION $\ldots \ldots \ldots \ldots \ldots \ldots \ldots \ldots \ldots \ldots \ldots \ldots \ldots \ldots \ldots \ldots \ldots \ldots \ldots$

2.0 GOALS AND OBJECTIVES $\ldots \ldots \ldots \ldots \ldots \ldots \ldots \ldots \ldots \ldots \ldots \ldots \ldots \ldots \ldots \ldots \ldots \ldots$

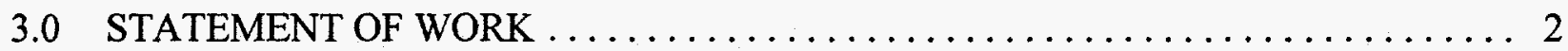

3.1 Subtask 1 - Collect Data on PFBC and Gasification Systems ............ 2

3.2 Subtask 2-Assemble CCT By-Product Management Information ........... 2

3.3 Subtask 3 - Finalize Energy \& Environmental Research Center (EERC) Report of Barriers to CCB Utilization ....................... 2

3.4 Subtask 4-Develop a CCT By-Product Workshop ................ 3

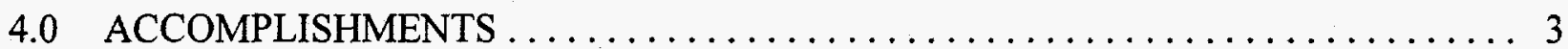

5.0 CONTINUING ACTIVITIES $\ldots \ldots \ldots \ldots \ldots \ldots \ldots \ldots \ldots \ldots \ldots \ldots \ldots \ldots$ 


\section{TASK 1.13 - DATA COLLECTION AND DATABASE DEVELOPMENT FOR CLEAN COAL TECHNOLOGY BY-PRODUCT CHARACTERISTICS AND MANAGEMENT PRACTICES}

\subsection{INTRODUCTION}

U.S. Department of Energy Federal Energy Technology Center-Morgantown (DOE FETC) efforts in the areas of fossil fuels and clean coal technology (CCT) have included involvement with both conventional and advanced process coal conversion by-products. In 1993, DOE submitted a Report to Congress on "Barriers to the Increased Utilization of Coal Combustion/Desulfurization Byproducts by Governmental and Commercial Sectors" that provided an outline of activities to remove the barriers identified in the report. DOE charged itself with participation in this process, and the work proposed in this document facilitates DOE's response to its own recommendations for action. The work reflects DOE's commitment to the coal combustion by-product (CCB) industry, to the advancement of clean coal technology, and to cooperation with other government agencies.

Information from DOE projects and commercial endeavors in fluidized-bed combustion (FBC) and coal gasification is the focus of this task. The primary goal is to provide an easily accessible compilation of characterization information on the by-products from these processes to government agencies and industry to facilitate sound regulatory and management decisions. Additional written documentation will facilitate the preparation of an updated final version of background information collected for DOE in preparation of the Report to Congress on barriers to CCB utilization.

The information assembled will be valuable to the Environmental Protection Agency (EPA) in its upcoming decision on the waste status of FBC by-products and must be submitted to EPA in April 1997. This effort facilitates interaction between DOE and industry regarding input to EPA. The effort of DOE FETC to provide this type of information to EPA is consistent with the recommendation in the DOE Report to Congress on ash barriers, that a determination placing CCT by-products under RCRA (Resource Conservation and Recovery Act) Subtitle D for solid wastes is needed if these materials are to be utilized. Several DOE projects have already investigated utilization of these materials, so this is an opportunity to give this information the emphasis it deserves.

\subsection{GOALS AND OBJECTIVES}

The primary goal of this task is to provide an easily accessible compilation of characterization information on CCT by-products to government agencies and industry to facilitate sound regulatory and management decisions. Supporting objectives are to 1) fully utilize information from previous DOE projects, 2) coordinate with industry and other research groups, 3 ) focus on by-products from pressurized fluidized-bed combustion (PFBC) and 
gasification, and 4) provide information relevant to the EPA evaluation criteria for the Phase II Bevill decision.

\subsection{STATEMENT OF WORK}

Details of the statement of work follow.

\subsection{Subtask 1 - Collect Data on PFBC and Gasification Systems}

Through literature, industrial and government contacts, and the research community, additional by-product and process data on PFBC and gasification systems will be collected and added to the database. Projects supported by DOE are expected to provide significant data for this subtask. This subtask will also use information from the same contacts and sources used in Subtask 1, but it is anticipated that additional contacts, sources, and information will need to be developed through the performance of a literature search, trade associations, and personal contacts at utility and industrial plants with these systems in place.

\subsection{Subtask 2 - Assemble CCT By-Product Management Information}

CCT by-products are relatively new to the CCB utilization industry, so the information collected in Subtask 1 may not include well developed by-product management information. A specific effort will be made to collect and include management options for PFBC and gasification by-products. Using all contacts and sources developed in the previous subtasks, these options will be identified with the intent to collect specific information on by-product utilization examples, demonstrations, and commercial applications.

\subsection{Subtask 3 - Finalize Energy \& Environmental Research Center (EERC) Report of Barriers to CCB Utilization}

The EERC assembled comprehensive information on $\mathrm{CCB}$ production, characteristics, and management options at the request of FETC prior to the submission of DOE's Report to Congress on "Barriers to the Increased Utilization of Coal Combustion/Desulfurization Byproducts by Governmental and Commercial Sectors." The draft EERC report focuses on utilization of CCBs and will have broad applicability for regulatory agencies and CCB users. This report requires revision prior to its being published by FETC, and these revisions will be accomplished according to review comments previously received from FETC. Since this report was originally prepared in 1993, it is also proposed to add an update to the report. This addition to the report will summarize 1) current production and management statistics, 2) regulatory and legislative activities involving CCBs, 3) impacts of technology changes, and 4) new utilization options and standards and specifications. 


\subsection{Subtask 4-Develop a CCT Byproduct Workshop}

Following the collection and submittal of the information on CCT by-products, the EERC will work with $\mathrm{DOE}$ and industry to develop a workshop designed to inform regulatory agencies and potential users about the properties and management options for CCT by-products.

\subsection{ACCOMPLISHMENTS}

This subtask has been under way since late October 1996. During the last six months, July 1, 1997, through December 31, 1997, the EERC modified the draft report titled "IGCC and PFBC By-Products: Generation, Characteristics, and Management Practices" based on review comments from industry and DOE partners in the integrated gasification combined cycle (IGCC) and $\mathrm{PFBC}$ projects represented in the report and to other interested government and industry representatives. The amended draft report was finalized, and a hard copy and an electronic copy of the report were submitted to EPA on September 30, 1997, which was the EPA deadline for submission of information to be reviewed for the Phase II Bevill waste determination. A copy of this report is attached. Unfortunately, full-scale by-product information was unavailable from two of the IGCC projects at the time of submission of that report.

Fortunately, the timeframe for the EPA determination on the status of the Phase II Bevill wastes has been extended by a period of 1 year, which provides an opportunity for DOE to respond to EPA with additional information from the two IGCC projects that are still assembling the required data. In follow-up conversations with Roy Dowd at the Wabash River Coal Gasification Repowering Project and Sherry Dawes at the Piñon Pine IGCC Power Plant, it was indicated that the required information will become available prior to the scheduled EPA decision late in 1998. In fact, the projected schedule for each of the IGCC projects would allow DOE to submit that information to EPA during the comment period that EPA will provide to industry and others prior to making its final determination. It is anticipated that the comment period will be scheduled for mid- to late 1998. Dennis Ruddy, the EPA staff member responsible for this determination, has indicated an interest in obtaining the remaining information on fullscale IGCC by-product characteristics and management. Industrial representatives at the IGCC projects have indicated that it would be beneficial for DOE to continue to utilize a contractor to follow up on the EPA waste determination and provide comments during the EPA comment period.

Work continued with DOE contractors at Radian International, Andy Weinberg and Becky Coel, to develop a joint technology transfer effort for state regulators on the issues related to CCT by-products. The collaborative effort with Radian International focused on two primary areas: 1) identifying state agency contacts to be included in the Radian database and 2) developing a presentation to be given at individual state agencies.

The state agency presentation was planned to be accomplished in a 1.5- to 2-hour timeframe, including opportunities for questions and discussion. An outline was developed for the presentation: 
1) Basic information on coal conversion processes and types of by-products

2) Summary of DOE research

3) Summary of current regulatory framework

4) A computer tour of related Web sites

5) Discussion period

Site visits were planned to include agencies in states from four primary regions in the United States: the West, Midwest, Southeast, and Northeast. Selection of specific states is still pending; however, it was determined to select states that are considered progressive as well as states that are still on the learning curve, so the presentation team can bring comments and expertise from one agency to others. It is typical that state agencies within a region tend to be aware of actions within their region, and these presentations can potentially facilitate the implementation regulations that remove barriers to increase $\mathrm{CCB}$ utilization in proven applications.

Work to revise the EERC's report on barriers to $\mathrm{CCB}$ utilization was also initiated during the last six months. A general review of the text was performed, and some editorial comments were made. The EERC professional technical editors will review these changes and perform their own edit on the document prior to submission to DOE. A new chapter was drafted for the barriers report. The chapter was developed at the request of the DOE project manager, with the goal of updating information relative to the state of CCB utilization in the United States. Several industrial groups were contacted for input to the report in order to properly reflect activities initiated by industry and the viewpoint of industry relative to progress in removing barriers to CCB utilization. A draft of the new chapter was sent to the DOE project manager for review.

\subsection{CONTINUING ACTIVITIES}

The EERC will continue to monitor EPA's schedule for the Phase II Bevill waste determination and will contact the DOE IGCC project staff for by-products to determine if the required information is available. Depending on the availability of that information, the EERC will prepare an addendum to the existing report on by-products from IGCC and PFBC which can be submitted to EPA during the comment period if DOE decides to proceed in that manner.

The collaborative effort with Radian International to develop technology transfer for state regulatory agencies will continue and is expected to be completed by June 30,1998 . The presentation will be finalized, and a schedule of meetings will be arranged. The site visits will commence during the first quarter of 1998. This subtask cannot be accomplished by the end date of the current task, so a time extension to June 30,1998, has been agreed upon by the EERC and the DOE project manager.

Preparation of a revised barriers report will continue. A draft should be available for review at the end of the first quarter of 1998. 